\title{
Media Sosial sebagai Saluran Aspirasi Kewargaan: Studi Pembahasan RUU Cipta Kerja
}

\author{
Bambang Arianto \\ Peneliti Institute for Digital Democracy \\ Email: ariantobambang2020@gmail.com
}

\begin{abstract}
ABSTRAK
Artikel ini bertujuan mengelaborasi peran media sosial sebagai saluran aspirasi kewargaan. Dikarenakan media sosial telah berperan dalam setiap sektor kehidupan kewargaan, seperti saluran informasi, interaksi, partisipasi, dan desentralisasi. Media sosial kemudian dipergunakan sebagai saluran untuk menyampaikan berbagai aspirasi warga negara dalam pembahasan Rancangan Undang-Undang Cipta Kerja. Berbagai komentar dukungan hingga penolakan yang konstruktif dan argumentatif hadir di media sosial sebagai bentuk partisipasi kewargaan. Artikel ini menggunakan pendekatan kualitatif deskriptif dengan berbasis data Drone Emprit yaitu aplikasi untuk menganalisis percakapan warganet di media sosial. Dengan demikian artikel ini berpendapat bahwa media sosial dapat berkontribusi positif sebagai saluran aspirasi kewargaan terutama dalam pembahasan RUU Cipta Kerja (Omnibus Law).
\end{abstract}

Kata Kunci: Media Sosial, Aspirasi Publik, Omnibus Law

\section{Social Media as A Citizenship Aspirations's Channel: Discussion Study Job Creation Bill (Omnibus Law's Bill)}

\section{ABSTRACT}

The purpose of this article is to elaborate roles of social media as a channel for civic aspiration. This is because social media has played a role in every sector of civic life, such as channels of information, interaction, participation, and decentralization. Social media is then used as a channel to convey the various aspiration of citizens in the discussion of the Job Creation Bill. Various comments of support to constructive and argumentative rejection appear on social media as a form of civic participation. This article uses a descriptive qualitative approach based on Drone Emprit data, which is an application for analyzing warganet conversations on social media. Thus this article argues that social media can contribute positively as a channel for citizenship aspiration, especially in the discussion of the Omnibus Law.

Keyword: Social Media, Publik Aspirations, Omnibus Law 


\section{PENDAHULUAN}

Salah satu varian dari teknologi informasi dan komunikasi yang semakin meluas penggunaannya hingga saat ini adalah media sosial. Fungsi media sosial sebagai media baru telah bergeser dari yang sekedar media sekunder, kemudian bertransformasi menjadi media primer yang dapat mempengaruhi sendi kehidupan warga negara (kewargaan). Dalam konteks ini media sosial merupakan sebuah kelompok aplikasi berbasis internet yang dibangun atas dasar ideologi dan teknologi web 2.0 serta memungkinkan penciptaan dan pertukaran user generated content. Dalam hal ini user generated content merupakan berbagai jenis konten baik video, meme, ulasan dan teks yang dibuat oleh warganet kemudian diunggah di media sosial masing-masing. Dengan begitu media sosial merupakan sebuah media berbasis kecanggihan teknologi yang diklasifikasikan dari berbagai bentuk seperti majalah, forum internet, weblog, blog sosial, microblogging, wiki, foto atau gambar, video peringkat dan bookmark sosial (Kaplan \& Haenlein, 2010).

Meski pada awalnya peran komunikasi kewargaan masih dipegang oleh media massa konvensional. Akan tetapi media massa konvesional dinilai belum mampu membangun sistem politik yang lebih demokratis. Hal itu diakibatkan masih tingginya komersialisme pasar media massa yang membuat adanya pengabaian peran komunikasi untuk tampil lebih demokratis bagi warga negara. Tetapi semenjak kehadiran media baru berbasis internet sangat potensial dalam mengubah kontur politik yang selama ini bersifat top down menjadi bottom up yang lebih partisipatif. Dengan cara kerja yang partisipasif membuat semakin terbukanya arus informasi, yang dapat membuka akses lebih luas bagi warga negara untuk melakukan otokritik. Dengan demikian dapat dikatakan media sosial telah berhasil menciptakan partisipasi digital yang lebih luas seperti membangun komunitas digital (Literat, et al, 2018).

Selain itu media baru telah menyediakan informasi politik dan gagasan yang hampir tidak terbatas, hingga komunikasi dua arah antara warga negara dan pemerintah sebagai pengambil kebijakan. Dengan begitu, media baru dapat menjadi semacam forum atau saluran baru bagi perkembangan kelompok kepentingan dan pembentukan opini kewargaan. Dengan begitu warga negara dapat mempergunakan komunikasi dua arah secara aktif tanpa campur pihak lain termasuk partai politik sekalipun. Dengan demikian, media baru telah dapat memberikan layanan ekspresi bagi warga negara tanpa ada batasan waktu dan ruang. Bahkan pihak otoritas tertinggi dalam hal ini pemerintah tidak mampu untuk mengendalikan akses pada 
penggunaan internet oleh warga negara yang berbeda pendapat (Coleman, et al, 1999).

Dengan demikian kehadiran media baru telah menghilangkan batasan maupun perantara antara publik dengan pengambil kebijakan yang dapat menciptakan komunikasi dua arah. Dengan kata lain media baru sangat ideal untuk dapat menempati ruang publik bagi masyarakat sipil di antara ranah pribadi dan otoritas negara. Dengan begitu media sosial dapat dikatakan sebagai ruang publik baru yang lebih terbuka untuk saluran interaksi, pertukaran gagasan hingga membangun komunikasi dua arah lainnya yang memungkinkan warga negara mengekspresikan aspirasinya (McQuail, 2005). Dengan demikian komunikasi yang berkembang dalam langgam media baru (internet) bisa dikatakan telah menciptakan kekebasan berekspresi, berinteraksi hingga ikut memperkuat proses desentralisasi (Castells, 2001).

Dengan begitu media sosial sebagai media baru secara dramatis telah dapat mengubah lanskap sosial dan cara memahami esensi partisipasi kewargaan (Lewis \& Rosen, 2010). Jadi tidak ayal bila kemudian terdapat beberapa faktor yang menyebabkan seseorang menggunakan media sosial sebagai sarana untuk interaksi, informasi, partisipasi dan desentralisasi. Pertama, sebagai sarana interaksi, media sosial telah banyak memberikan konstribusi bagi kewargaan untuk saling berinteraksi, karena tidak dibatasi oleh waktu, ruang, maupun tempat. Alhasil, melalui media sosial, seseorang dapat menemukan pertemanan yang selama ini tidak ditemui. Sarana interaksi ini semakin meluas karena media sosial memiliki ruang khusus untuk membangun komunitas. Hal itu dapat dilihat dari tumbuhnya grup-grup berbasis komunitas di media sosial Facebook. Dari grup keluarga hingga alumni sekolah. Hampir semua komunitas memanfaatkan grup Facebook untuk dapat membangun interaksi yang memang tidak dapat diraih dalam luar jaringan (luring). Sedangkan dalam konteks bisnis diketahui bahwa manfaat dari media sosial dapat meningkatkan frekuensi kunjungan pelanggan (Rishika, 2013). Meski demikian akibat dari pemanfaatan media sosial sebagai media interaksi secara berlebihan seringkali mendorong fenomena ketergantungan terhadap konten. Sehingga warganet seringkali tergerak menciptakan konten yang dapat viral atau tersebar luas dengan segala cara termasuk melakukan prank (akal-akalan). Hal ini tampak dari aksi yang dilakukan Yotuber Ferdian Faleka yang melakukan prank sembako ke waria hanya bertujuan meningkatkan follower di Youtube (cnnindonesia.com, 2020). 
Lebih lanjut, media sosial dapat menjadi saluran informasi. Apalagi media sosial dapat digunakan untuk melakukan koordinasi hingga menyebarkan informasi kritis dengan lebih efisien (Enikolopov, et. al, 2019). Hal itu dapat dilacak dari konten yang viral tentu akan banyak menjadi bahan perbincangan publik. Ini yang kemudian membuat isu terkini yang berasal dari media sosial seringkali dijadikan pemberitaan utama oleh media massa konvensional. Dengan begitu dapat dikatakan bahwa warga negara saat ini lebih cenderung mencari informasi terkini dari media sosial daripada media massa konvensional. Apalagi saat ini setiap daerah di Indonesia memiliki akun publik berbasis kedaerahan yang seringkali memberikan informasi terkini tentang daerah masingmasing dengan cepat. Akibatnya publik lebih menyukai akun media sosial berbasis kedaerahaan dalam mencari informasi terkini tentang daerah masing-masing. Selain itu, media sosial lebih cepat dalam menampilkan informasi terkini yang menyebabkan publik lebih cepat mendengar informasi dari media sosial daripada media massa konvensional. Sehingga tidak ayal bila terjadi ketergantungan publik dengan media sosial lebih tinggi daripada media massa konvensional. Ini yang kemudian menyebabkan banyak sumber pemberitaan media massa konvensional berasal dari isuisu terkini yang terjadi di media sosial.

Lebih lanjut, media sosial dikenal sebagai saluran partisipasi dapat dikatakan sebagai media bagi publik untuk ikut berpartisipasi aktif dalam berbagai hal terutama untuk menyingkapi dan mengkritisi berbagai kebijakan. Termasuk dalam menyalurkan aspirasi terhadap berbagai kebijakan dari pemerintah daerah setempat. Sebab, perkembangan teknologi digital telah dapat mengubah sistem pemerintahan dengan membuka peluang bagi setiap warga negara untuk secara langsung mempengaruhi berbagai kebijakan dalam konteks demokrasi (LunaReyes, 2017). Dengan kata lain media sosial telah memberikan peluang bagi warga negara dalam mengkritisi dan memberikan gagasan konstruktif. Bahkan diketahui peran dari saluran media sosial telah banyak melahirkan gerakan sosial hingga gerakan politik sebagai bagian dari partisipasi publik. Hal itu dapat dilacak dari kehadiran fenomena relawan politik sejak 2012 hingga saat ini (Arianto, 2019). Sedangkan dalam konteks ini partisipasi bisa dikatakan secara aktif untuk mendukung, mengawasi dan mengkritisi sebuah kebijakan. Aspirasi ini dapat berupa otokritik, protes maupun masukan terhadap berbagai kebijakan publik yang telah dibangun oleh pemerintah. Dalam hal ini warga negara dapat dengan bebas 
menggunakan media sosial untuk berbagai saluran aspirasi dan partisipasi publik. Artinya, media sosial telah mampu mendorong partisipasi warga negara lebih besar (Effing, et. al, 2011).

Terakhir media sosial dapat dikatakan menjadi sarana desentralisasi yakni sebagai sarana untuk dapat lebih mendekatkan diri antara pemerintah dan warga negara. Sebab media sosial telah membentuk ruang publik baru tanpa sekat. Dengan begitu warga negara akan ikut berpartisipasi untuk menyampaikan berbagai aspirasinya melalui media sosial. Dengan kedekatan antara pemerintah dan publik tentulah akan memperpendek rantai birokrasi sehingga akan dengan mudah mewujudkan transparansi sebagai pilar demokratisasi. Dalam hal ini media sosial terdiri atas tiga bagian yakni; Pertama, infrastruktur informasi dan alat yang digunakan untuk memproduksi dan mendistribusikan konten. Kedua, konten digital yang berasal dari pesan pribadi, berita, ide, dan produk budaya lainnya. Ketiga, organisasi, perseorangan dan industri yang memang menghasilkan dan mengkonsumsi konten digital (Howard \& Malcolm, 2012). Lebih lanjut media sosial juga berpengaruh terhadap pembentukan politik kontemporer yang demokratis. Seperti forum diskusi online yang memberi kebebasan untuk mengekspresikan dan memberdayakan diri (Loader \& Dan,
2011). Dengan demikian, kehadiran media sosial telah mendorong aksi kolektif yang bisa menciptakan partisipasi politik berskala besar sehingga dapat membentuk partai hingga organisasi transnasional (Bennett, 2012).

Kebermanfaatan dari media sosial membuat media baru ini menjadi saluran aspirasi para warga negara. Melalui media sosial, publik dapat dengan mudah untuk memberikan masukan hingga mengkritisi berbagai persoalan politik dan pemerintahan. Hal ini membuat masyarakat sipil yang ingin menolak Rancangan Undang-Undang (RUU) Cipta Kerja (Omnibus Law) memanfaatkan media sosial dalam membangun propaganda digital hingga gerakan sosial untuk melakukan aksi demontrasi. Penggunaan media sosial oleh warganet untuk melakukan kritik dan penolakan terhadap RUU Cipta Kerja kemudian mengonfirmasi bahwa media sosial telah mendorong tumbuhnya partisipasi digital. Seperti dalam penolakan RUU Cipta Kerja, para simpul masyarakat sipil telah menggunakan media sosial sebagai alat propaganda digital. Dari propaganda digital inilah yang dapat menciptakan berbagai aksi-aksi demonstrasi di setiap daerah di Indonesia. Dengan begitu dapat dikatakan informasi dari media sosial dapat memiliki dampak langsung pada partisipasi politik offline yang dimediasi melalui ekspresi politik (Gil 
de Zúñiga, et al, 2014). Sehingga penggunaan media sosial telah menciptakan berbagai peluang partisipasi kewargaan sekaligus memediasi kesadaran politik kewargaan yang lebih luas (Lee, et. al, 2017).

Penelitian ini akan fokus pada pembahasan peran media sosial sebagai saluran aspirasi kewargaan dengan menganalisis pembahasan RUU Cipta Kerja (Omnibus Law). Beberapa studi sebelumnya telah menjelaskan bahwa media sosial berperan sebagai saluran aspirasi kewargaan (Jati, dkk, 2018). Sedangkan penelitian ini ingin mengkonfirmasi lebih lanjut mengenai peran media sosial sebagai saluran aspirasi kewargaan berbasis percakapan warganet. Penelitian ini lebih menekankan pada elaborasi percakapan warganet di media sosial Twitter dan Instagramdengan merujuk data dari Drone Emprit. Dengan demikian, dapat dikatakan studi ini hendak membuktikan bagaimana peran media sosial menjadi saluran aspirasi kewargaan seperti yang dikemukakan oleh studi sebelumnya. Sedangkan batasan dan implikasi dalam penelitian ini hanya fokus pada peran media sosial sebagai saluran aspirasi kewargaan.

\section{METODOLOGI}

Metode penelitian ini menggunakan pendekatan kualitatif deskriptif dengan studi kasus pada pembahasan Rancangan Undang-Undang (RUU) Cipta Kerja. Pendekatan studi kasus merupakan salah satu pendekatan kualitatif yang didisain untuk mengelaborasi proses atau perilaku baru sebagai obyek penelitian yang belum banyak dipahami secara luas (Dobson, 1999). Penelitian ini akan berbasis data percakapan media sosial dari Drone Emprit. Dalam hal ini Drone Emprit merupakan sebuah aplikasi yang dapat menganalisis jejaring percakapan warganet di media sosial secara spesifik secara semi-realtime dan detail. Teknik pengumpulan data dari Drone Emprit terhadap percakapan warganet menggunakan Social Network Analysis (SNA) yang juga menyerupai Drone Emprit Academic (Arianto, 2020c). Durasi waktu dalam aplikasi Drone Emprit bisa digunakan untuk memantau percakapan real time saat analisis hingga rentang waktu selama satu bulan (Fahmi, I, 2019b). Sedangkan rentang waktu data percakapan di Twitter dan Instagramantara tanggal 28 September hingga 5 Oktober 2020. Selain itu Drone Emprit merupakan suatu sistem aplikasi yang bisa menganalisis percakapan media sosial dan berbagai online platform berbasis teknologi big data dengan menggunakan artifial intelligence (AI) dan natural learning process (NLP). Melalui Drone Emprit, penelitian ini akan dengan mudah menganalisis sumber percakapan, 
persebaran dan kluster mana saja dari warganet yang terlibat dalam topik penelitian.

\section{HASIL DAN PEMBAHASAN Warganet dan Partisipasi Digital}

Masyarakat digital atau dikenal warganet memiliki ketergantungan yang tinggi terhadap media sosial, seiring kebermanfaatan dari media sosial yang semakin luas. Hal itu tampak dari semakin meningkatnya penggunaan media sosial di kalangan generasi muda Indonesia saat ini. Menurut laporan Hootsuite dalam Digital Around The World 2020 menunjukan bahwa pengguna media sosial di Indonesia pada tahun 2020 sekitar 160 juta dengan penetrasi 64 persen. Platform media sosial yang paling digunakan di Indonesia per Januari 2020 adalah Youtube (88 persen), Whatsapp (84 persen) Facebook (82 persen), Instagram(79 persen) dan Twitter (56 persen). Sedangkan dari sisi usia pengguna yang paling banyak menggunakan media sosial berasal dari 18 - 24 tahun dengan rincian 16,1 persen untuk berjenis kelamin laki-laki dan 14,2 persen perempuan. Selain itu untuk usia 2534 tahun dengan rincian 20,6 persen berjenis kelamin laki-laki dan 14,8 persen untuk perempuan (Rcfra, 2021).

Data tersebut mengonfirmasi bahwa tingginya penggunaan media sosial menjadi bukti semakin berperanya media sosial dalam semua sektor kehidupan terutama dalam membangun partisipasi kewargaan. Partisipasi ini meliputi upaya mengawasi dan mengkritisi berbagai persoalan riil rakyat hingga pada berbagai kebijakan yang digulirkan oleh pengambil kebijakan yaitu pemerintah. Media sosial kemudian dapat menjadi saluran untuk membangun partisipasi digital. Dalam konteks ini partisipasi yang bersumber dari media soal telah mendorong publik untuk berani melakukan protes secara digital, hingga keberanian menolak sebuah kebijakan yang telah digulirkan oleh otoritas pemerintah.

Dengan begitu, partisipasi digital kemudian dapat menjadi ciri khas utama dari masyarakat digital. Meski begitu dalam masyarakat digital dikenal berbagai klasifikasi warganet yaitu; follower, buzzer dan influencer. Beberapa studi sebelumnya menyatakan bahwa follower merupakan akun media sosial yang mengikuti akun yang kita miliki. Kemudian, ada buzzer yaitu akun media sosial yang setiap saat mendengungkan, mengemakan, mempromosikan, mengkampanyekan informasi, produk dan jasa kepada warganet. Sedangkan untuk buzzer dibedakan antara buzzer bisnis dan buzzer politik. Terakhir yaitu influencer yaitu akun media sosial yang memiliki banyak follower dan sangat memiliki mempengaruhi yang kuat kepada para 
follower-nya untuk berbuat seperti kehendaknya (Arianto, 2020a; 2020b).

Tabel 1. Klasifikasi Aktor Warganet

\begin{tabular}{clll}
\hline & $\begin{array}{c}\text { Follo } \\
\text { wer }\end{array}$ & \multicolumn{1}{c}{ Buzzer } & $\begin{array}{c}\text { Influence } \\
\boldsymbol{r}\end{array}$ \\
Defin & Akun & Akun & Akun \\
isi & media & media & media \\
& sosial & sosial yang & sosial \\
& yang & setiap saat & yang \\
& mengi & mendengun & dapat \\
kuti & gkan atau & mempeng \\
akun & mengkamp & aruhi \\
yang & anyekan & parafollo \\
kita & pesan & wernya \\
miliki & kepada & untuk \\
& . & warganet. & berbuat \\
& & seperti \\
& & & kehendak \\
& & & nya.
\end{tabular}

\begin{tabular}{|c|c|c|c|}
\hline $\begin{array}{l}\text { Sifat } \\
\text { Aku } \\
\text { n }\end{array}$ & $\begin{array}{l}\text { Anom } \\
\text { in dan } \\
\text { nyata }\end{array}$ & $\begin{array}{l}\text { Akun Real } \\
\text { (Positif) } \\
\text { Akun } \\
\text { Anonim } \\
\text { (Negatif) }\end{array}$ & $\begin{array}{l}\text { Mayoritas } \\
\text { akun } \\
\text { nyata } \\
\text { (real) }\end{array}$ \\
\hline $\begin{array}{l}\text { Juml } \\
\text { ah } \\
\text { Follo } \\
\text { wer }\end{array}$ & $1-500$ & $\begin{array}{l}\text { Akun } \\
\text { Positif > } \\
500 \\
\text { Akun } \\
\text { Negatif < } \\
500\end{array}$ & $>10.000$ \\
\hline
\end{tabular}

Sumber diolah peneliti (2021)

Lebih lanjut, fungsi follower merupakan sebagai penerima akhir pesan dari buzzer dan influencer terutama berperan menyebarluaskan pesan dari buzzer dan influencer. Sedangkan fungsi buzzer yaitu; membentuk opini publik dalam ranah media sosial dengan menempati trending topic Twitter. Kategori buzzer media sosial dibedakan yaitu buzzer bisnis dan politik. Untuk buzzer bisnis hanya terfokus pada membangun citra positif (supporting) dan mengklarifikasi citra (defensif). Sedangkan untuk buzzer politik fokus pada (1) Membangun citra positif (supporting), (2) Mengklarifikasi citra bila ada kampanye hitam (defensif) (3) Menyerang dan merusak citra pesaing (offensive). Terakhir ikut memperkuat pesan atau konten dari influencer melalui repost, retweet dan reshare hingga pesan tersebut viral di semua media sosial. Lebih lanjut aktor media sosial lainnya yaitu influencer berperan sebagai; 1) Membangun ide awal bagi pembentukan opini publik yang diteruskan oleh buzzer dan follower melalui trending topik Twitter. 2) Membangun isu dan opini melalui proses investigasi individual dan jurnalisme warga. Tujuannya untuk membantu para follower memahami informasi terbaru yang lagi tren saat ini. 3) Menciptakan berbagai tagar yang ditargetkan dapat menjadi trending topik di Twitter. Meski begitu ciri khas dari akun influencer adalah bergerak secara individual dan lebih berpegang pada pendapat pribadi sesuai isu yang lagi trending.

Lebih lanjut dalam pembahasan RUU Cipta Kerja, masyarakat sipil tidak tidak hanya menghandalkan gerakan luar jaringan (luring) dalam menyuarakan aspirasinya. Apalagi ditengah pandemi Covid-19 membuat aksi massa dengan turun ke jalan tentu tidak begitu efektif karena akan melanggar protokol kesehatan. 
Hal ini sangat berbeda dengan aksi \#GejayanMemanggil yang dapat mendorong para mahasiswa dan semua elemen masyarakat sipil untuk turun ke jalan. Pandemi Covid-19 membuat simpul masyarakat sipil yang terdiri dari mahasiswa, gerakan buruh, hingga akademisi membangun aksi penolakan dengan diawali oleh propaganda digital di media sosial terlebih dahulu. Oleh sebab itu dalam penelitian ini akan dielaborasi mengenai berbagai aksi penolakan publik terhadap RUU Cipta Kerja yang disalurkan melalui media sosial. Dengan kata lain, media sosial pada saat pandemi Covid-19 menjadi satu-satunya saluran untuk menyampaikan aspirasi terhadap pembahasan RUU Cipta Kerja, baik yang menolak maupun yang mendukung. Dengan begitu media sosial telah menjadi saluran untuk melakukan protes digital para warganet.

Tidak ayal, bila dicermati secara organik semua simpul masyarakat sipil yang menolak RUU Cipta Kerja selalu memulai aksi propaganda penolakan dengan media sosial. Sehingga tidak salah dalam rentang waktu itu berbagai konten propaganda digital yang menolak RUU Cipta Kerja dapat ditemui di timeline media sosial. Persebaran konten digital yang massif ini agar dapat mendorong partisipasi publik yang lebih luas. Gerakan propaganda digital ini dapat ditemui di platform media sosial seperti Twitter, Instagram, Facebook hingga Whatsapp. Menariknya, agar gerakan penolakan terhadap RUU Cipta Kerja ini dapat dikenal luas oleh publik terutama warganet, para inisiator gerakan ini menggunakan media sosial Twitter. Hal itu disebabkan platform Twitter merupakan media sosial yang dapat dengan cepat memviralkan konten karena Twitter memiliki trending topik berbasis kata kunci (keyword).

\section{Media Sosial sebagai Saluran Aspirasi Warganet}

Berbagai aksi protes digital yang dilakukan oleh warganet di media sosial yaitu dengan mengunggah berbagai konten penolakan terhadap RUU Cipta Kerja (Omnibus Law). Meski begitu terkadang konten ini tidak lepas dari kemunculan konten hoaks yang membuat timeline media sosial menjadi semakin gaduh. Akan tetapi, peran media sosial dapat membuat para simpul gerakan penolakan RUU Cipta Kerja merasa terbantu dalam melakukan propaganda digital. Partisipasi digital ini mencerminkan bahwa media sosial telah banyak memberikan kontribusi nyata dalam menyalurkan aspirasi para warganet yang menolak RUU Cipta Kerja. Menariknya dari para mahasiswa dan simpul masyarakat sipil yang menolak RUU Cipta Kerja seringkali menggunakan teknik propaganda digital yang sama dilakukan oleh para 
buzzer politik dalam membangun opini publik. Hal itu dapat dilacak dari seruan para mahasiswa yang akan mengelar aksi demonstrasi, untuk bersama-sama menggunakan platform Twitter untuk membangun pemahaman isu bersama antar gerakan mahasiswa. Alhasil seruan ini disambut baik oleh seluruh mahasiswa di Indonesia yang kemudian banyak mengaktifkan akun Twitternya untuk bisa ikut memperkuat kampanye propaganda digital tersebut. Dengan kata lain, penggunaan platform Twitter dapat ikut memperkuat pesan dari konten penolakan di media sosial.

Seruan propaganda digital dari Twitter membuat beberapa tagar (hashtags) yang digulirkan oleh para mahasiswa dalam menolak RUU Cipta Kerja menjadi trending topik di Twitter dan bahkan menjadi trending topik dunia. Artinya, kekuatan tagar (hashtags) yang digulirkan para mahasiswa ini secara otomatis telah membuat media massa konvensional ikut menjadikan sebagai sumber pemberitaan. Hal itulah yang membuat isu penolakan RUU Cipta Kerja (Omnibus Law) ini semakin menjadi pembicaraan publik. Alhasil, hingga beberapa hari pemberitaan di media massa konvensional lebih banyak mengadopsi informasi terkini dari media sosial. Dengan begitu, aksi penolakan digital dengan menggunakan saluran media sosial telah terbukti mampu membangun propaganda digital yang sistematis hingga menjadi pembicaraan publik. Dengan kata lain, dalam pembahasan RUU Cipta Kerja media sosial memiliki peran yang sangat besar dalam membangun isu penolakan sehingga menjadi bahan percakapan para warganet dan publik secara umum.

Penelitian ini akan mengelaborasi data percakapan dari warganet pengguna media sosial Twitter dan Instagram. Dalam percakapan ini diketahui ada beberapa kata kunci yang paling banyak dibicarakan oleh warganet. Dalam menganalisis percakapan warganet tentang RUU Cipta Kerja, peneliti menggunakan aplikasi berbasis data besar (big data) yaitu Drone Emprit. Melalui software Drone Emprit ini dapat diketahui profil para warganet yang ikut terlibat dalam membicarakan RUU Cipta Kerja. Meski begitu gerakan penolakan atas RUU Cipta Kerja saat massa pandemi Covid-19 tidak lebih masif daripada awal pembahasan yang telah menimbulkan berbagai gelombang aksi demontrasi. Hal itu membuat media sosial menjadi pilihan terbaik dalam melakukan aksi propaganda digital. Dengan kata lain, ditengah pandemi Covid-19 membuat penolakan akan pengesahan RUU Cipta Kerja hanya bertumpu pada media sosial.

\section{Analisis Percakapan di Twitter}

Dari beberapa percakapan yang terjadi di Twitter dan Instagramdengan 
rentang rentang waktu 28 September hingga 5 Oktober 2020 tercatat beberapa kluster yang terbentuk. Dalam analisis Social Network Analysis (SNA) Drone Emprit hanya terdapat 2000 percakapan per hari di media sosial Twitter. Baru pada tanggal 4 Oktober 2020 kemudian meningkat pesat menjadi 57.000. Sedangkan pada tanggal 5 Oktober menjadi 50.000 percakapan di timeline Twitter. Kenaikan ini dipicu adanya keinginan dari DPR yang akan mengesahkan RUU ini menjadi Undang-Undang. Sehingga isu akan disahkan RUU Cipta Kerja membuatcpara mahasiswa dan kelompok yang tidak setuju dengan RUU Cipta Kerja berusaha melakukan penolakan melalui media sosial masing-masing. Dari data Drone Emprit diketahui peta Social Network Analisys (SNA) berdasarkan beberapa kluster.

\section{Gambar 1. Social Network Analysis (SNA) Drone Emprit}

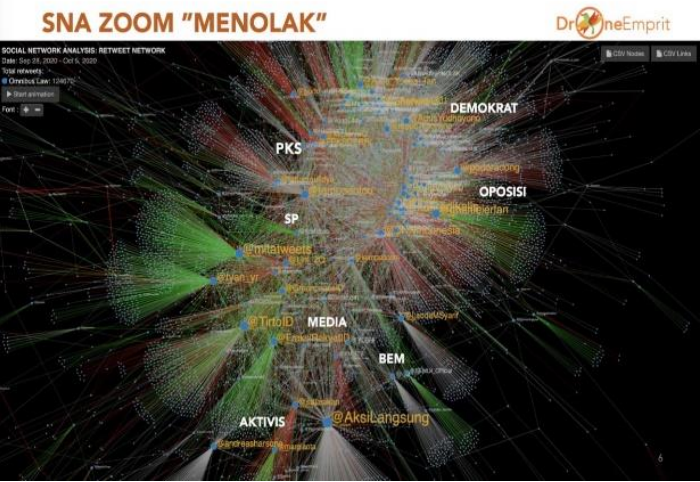

Sumber: pers.droneemprit.id
Gambar 2. SNA Drone Emprit

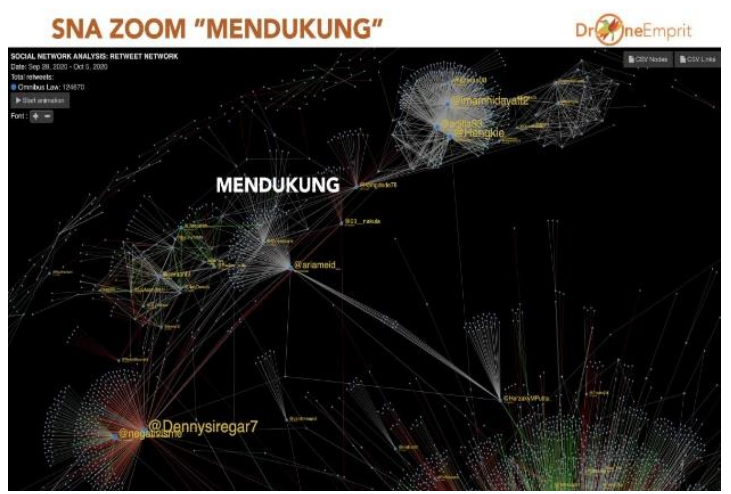

Sumber: pers.droneemprit.id

Dari data SNA Drone Emprit menunjukan ada beberapa kluster yang melakukan penolakan terhadap RUU Cipta Kerja. Dari kluster yang melakukan penolakan, berasal dari pihak oposisi berasal dari wakil partai politik seperti, partai Demokrat dan Partai Keadilan Sejahtera (PKS). Kemudian ada kluster dari para aktivis yang berasal dari semua simpul gerakan dan lembaga swadaya masyarakat. Kluster berikutnya berasal dari Badan Eksekutif Mahasiswa (BEM) yang merupakan simpul gerakan utama dari penolakan RUU Cipta Kerja. Terakhir diketahui dari kluster media massa baik media siber maupun konvensional yang ikut melakukan penolakan melalui Twitter. Lebih lanjut dari data SNA Drone Emprit juga diketahui kluster 
yang memberikan dukungan penuh pada RUU Cipta Kerja. Meski demikian kluster yang memberikan dukungan tidak sebesar dari yang menolak. Kluster yang mendukung hanya berasal dari para influencer dan para relawan politik yang masih setia dengan pemerintahan Presiden Joko Widodo. Dari data SNA Drone Emprit ini bisa dianalisis bahwa kluster yang menolak RUU Cipta Kerja ternyata lebih besar dari kluster yang memberikan dukungan.

Lebih lanjut dalam percakapan di Twitter, Drone Emprit juga menampilkan para akun-akun yang berkategori influencer dan buzzer. Dalam percakapan di Twitter dapat dikenal para aktor warganet yang sangat mempengaruhi linimasa media sosial. Untuk akun yang menjadi inisiator dan dapat mempengaruhi perhatian warganet dikenal sebagai yaitu top influencer. Di platform Twitter ditemukan ada beberapa influencer yaitu, akun @AksiLangsung dengan total interaksi 6,186, @TirtoID dengan interaksi 5,080, @mitatweets dengan interaksi 4,037, @ Kafiradilakis dengan interaksi 3,691 dan @podaradong dengan interaksi 3,564. Para top influencer ini mayoritas dalam percakapannya menolak adanya RUU Cipta Kerja. Sedangkan peran dari para influencer ini telah menarik atensi para warganet lainnya terus memperkuat opini publik atas penolakan RUU Cipta Kerja di media sosial Twitter. Meski begitu, aksi penolakan di Twitter juga dapat ditemukan di platform media sosial lainnya. Dikarenakan para top influencer juga memiliki platform media sosial lainnya seperti, Facebook, Instagramdan Youtube.

\section{Gambar 3 Top Hashtags (Tagar)}

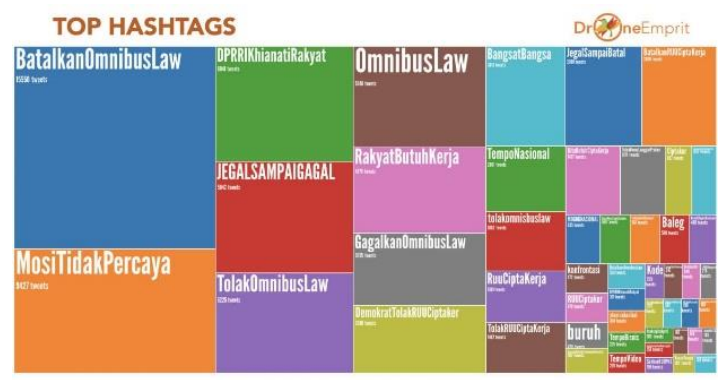

Sumber : pers.droneemprit.id

Dalam analisis percakapan ini diketahui saluran aspirasi warganet melalui media sosial diketahui dari menguatnya beberata tagar (hashtags) di Twitter. Sebab tagar (hashtags) menjadi ikon utama dari bentuk percakapan yang terjadi di media sosial. Dengan kata lain peran dan fungsi tagar sangat penting untuk memberikan identifikasi tersendiri atas isu-siu yang tengah berkembang. Di media sosial Twitter peran dari tagar (hashtags) sangat menentukan agar isu tersebut dikenal luas warganet atau tidak. Dalam percakapan ini ditemui beberapa tagar yang dominan diantaranya; \#BatalkanOmnibusLaw dan \#MosiTidakPercaya. Peran dari tagar ini dapat menjadi simbol dari bentuk 
penolakan para warganet atas RUU Cipta Kerja. Apalagi bila dilihat dari frasa yang digunakan semua menggunakan kata kunci penolakan. Lebih lanjut, tagar (hashtags) \#MosiTidakPercaya telah digunakan sebanyak 1,5 juta cuitan. Besarnya penggunaan tagar (hashtags) sebagai bukti bahwa warganet menjadikan media sosial sebagai saluran aspirasinya dalam menolak RUU Cipta Kerja. Dengan jumlah yang besar ini membuat tagar ini menjadi trending topik dunia dan bisa menarik perhatian dunia internasional. Meski begitu, data Drone Emprit, diketahui bahwa ada komunitas KPopers yang selama ini tidak paham mengenai RUU Cipta Kerja, kemudian ikut serta untuk memberikan penolakan. Para pegiat KPopers yang telah memahami akan RUU Cipta Kerja kemudian bersatu untuk memperkuat tagar \#MosiTidakPercaya dan beberapa tagar (hashtags) yang kemudian menjadi trending topik dunia.

Lebih lanjut dalam melakukan penolakan terhadap RUU Cipta Kerja para warganet menggunakan konten-konten sebagai bentuk perlawanan dan sindiran. Dari propaganda digital yang dilakukan oleh warganet diketahui beberapa konten yang bermaterikan penolakan. Untuk Twitter ada beberapa bentuk konten yang paling banyak digunakan dalam menolak RUU Cipta Kerja.
Gambar 4 Top Shared Images

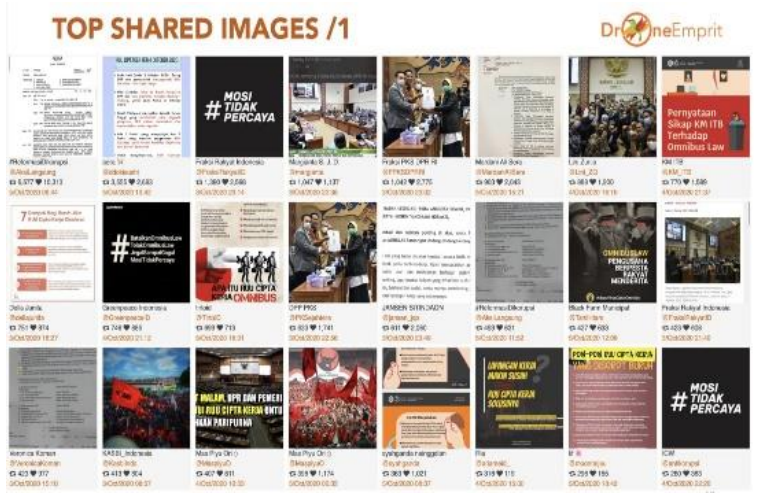

Sumber : pers.droneemprit.id

Konten merupakan salah satu ikon dari saluran warganet yang bisa digunakan untuk mendukung maupun menolak sebuah isu kekinian. Di Twitter diketahu ada beberapa konten yang bermaterikan foto, meme hingga video. Konten ini digunakan untuk melakukan protes secara digital terhadap pembahasan RUU Cipta Kerja. Dalam percakapan tentang RUU Cipta Kerja, ternyata konten yang sangat dominan menguasai lini massa media sosial adalah meme dan infografis yang bermaterikan penolakan. Dengan begitu, dalam penolakan RUU Cipta Kerja diketahui beberapa konten yang cukup digemari oleh warganet seperti konten dari akun @AksiLangsung yang disukai sebanyak 10,313 dan di retweet sebanyak 6,577 kali oleh warganet. Dalam konten tersebut dijelaskan beberapa draf dari RUU Cipta Kerja yang terkesan ambigu atau merugikan pihak pekerja dan buruh di Indonesia. Sedangkan beberapa konten lainnya yang diunggah juga mendapat 
respon yang positif oleh warganet. Dengan demikian, pemilihan konten menjadi kunci penting dalam menyalurkan aspirasi melalui media sosial. Tanpa konten tentulah menjadi saluran aspirasi yang disampaikan oleh warganet tidak akan bisa menarik perhatian publik.

Lebih lanjut, dari data Drone Emprit diketahui terdapat beberapa narasi yang cukup banyak mendapatkan atensi dari warganet. Komentar ini bermaterikan kritikan atas pembahasan RUU Cipta Kerja yang tiba-tiba akan segera disahkan. Beberapa warganet yang menjadi top influencer banyak memberikan otokritik sekaligus seruan untuk bersama-sama membatalkan RUU Cipta Kerja, seperti yang diutarakan akun @AksiLangsung bahwa "Wuiih Telegram Kapolri ngerii selain melarang unjuk rasa (padahal sudah dijamin oleh konstitusi) juga melakukan counter narasi soal Cipta Kerja. Benar polisi sekarang polisi propaganda palugada bisa jadi tukang pukul plus buzzer. Gini nih preman diseragamin kayak gini”. Unggahan tersebut di Twitter ingin menjelaskan bahwa ada upaya dari pihak berwenang untuk menekan para masyarakat sipil yang menolak RUU Cipta Kerja dengan memanfatkan berbagai propaganda termasuk penggunaan buzzer media sosial.

Sedangkandari akun@mitatweets menyatakan kegelisahannya karena RUU Cipta Kerja akan segera disahkan. Sehingga meminta seluruh simpul masyarakat sipil untuk tidak diam dan harus melawan RUU Cipta Kerja. Seperti unggahnya di Twitter berikut ini; “ Alerta! Aku minta perhatian teman-teman semua Omnibus Law mendekati paripurna. Kalau disahkan, hak tanah dan linkungan kita habis dijual. Kita tidak bisa diam saja. Taruhannya masa depan kita semua. Kumpulin tenaga, kumpulin kawan, Lawan. \#BatalkanOmnibusLaw. Lebih lanjut akun (@tyan_yr menyatakan bahwa bila RUU Cipta Kerja disahkan, maka telah mengkhianati semangat demokrasi terutama perihal reformasi agrarian. Seperti yang disampaikan di Twitter sebagai berikut; "Dalam kurun satu tahun pemerintahan Joko Widodo berhasil memutar jarum jam kembali ke pra 1998; memangkas kewenangan KPK dan jika benar nanti malam Omnibus Law disahkan, itu mengencingi spirit TAP MPR XVI/1998 tentang demokrasi ekonomi dan TAP MPR IX/2001 tentang reforma agraria dan Sumber Daya Alam". Berbagai komentar dari warganet menunjukan media sosial menjadi satu-satunya saluran untuk menyampaikan dan meluapkan kegelisahan akan rencana disahkanya RUU Cipta Kerja.

Lebih lanjut, indikator lain dalam penelitian ini adalah menakar seberapa besar para warganet yang melakukan percakapan terindikasi akun robot (BOT). Sebab banyak yang bertanya-tanya apakah 
akun-akun yang melakukan penolakan tersebut benar berasal dari suara warga negara ataukah hanya sebatas akun robot. Berikut beberapa analisis BOT dari data Drone Emprit berikut ini;

\section{Gambar 5. Analisis Bot}

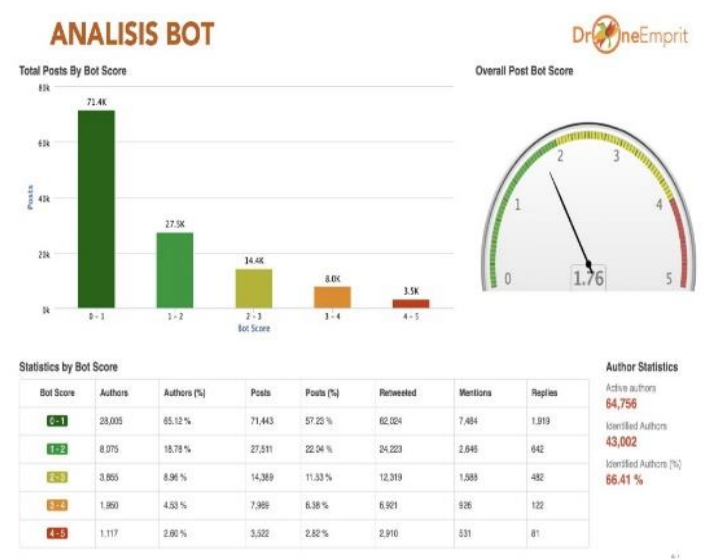

Sumber : pers.droneemprit.id

Dalam analisis BOT diketahui terdapat total 64.000 akun yang aktif terlibat dalam percakapan tentang RUU Cipta Kerja. Dari jumlah tersebut ada sebanyak 66,41 persen yang berhasil dideteksi berstatus bot-nya. Sedangkan skor keseluruhan postingan berdasarkan bot diketahui sebanyak 1,76. Dengan begitu angka sebesar 1,76 mengonfirmasi bahwa akun robot yang cukup kecil atau sekitar 1,76 yang membuktikan percakapan yang terjadi di Twitter sangat natural. Dengan kata lain, percakapan yang terjadi bukan rekayasa apalagi manipulasi semata. Dengan demikian, bisa disimpulkan bahwa percakapan yang terjadi atas pembahasan RUU Cipta Kerja baik yang menolak maupun mendukung merupakan wujud aspirasi publik yang diwakilkan oleh para warganet. Hal ini semakin menegaskan bahwa media sosial sebagai saluran aspirasi kewargaan terkait pembahasan RUU Cipta Kerja (Omnibus Law).

\section{Analisis Percakapan di Instagram}

Mengingat media sosial mayoritas digunakan oleh para generasi milenial dan generasi $\mathrm{Z}$, tentulah harus dianalisis dari platform Instagram. Platform ini merupakan salah satu platform media sosial yang menjadi terfavorit para warganet yang dapat dikategorikan generasi milenial. Dalam pembahasan RUU Cipta Kerja, platform Instagrambanyak digunakan para mahasiswa untuk menarik partisipasi teman sekampus agar ikut bersama-sama menolak RUU Cipta Kerja.

\section{Gambar 6 Most Liked Images (Instagram)}

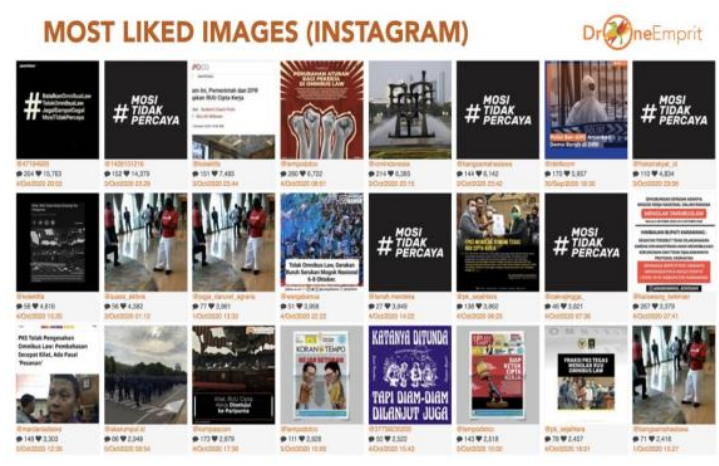

Sumber : pers.droneemprit.id

Akan tetapi, untuk Instagrambentuk saluran aspirasi sangat bergantung pada konten yang diunggah setiap feed Instagram. Dengan begitu, tanpa konten yang menarik tentulah akan sulit menarik perhatian warganet lainnya. Dalam analisis 
Drone Emprit, diketahui konten yang paling banyak mendapatkan tanda suka (like) yang berasal dari top influencer yaitu akun@GreenoeadeID debfab 16,707, @tempodotco dengan 16, 136, @kolektifa dengan 15, 230, @marganamahendra dengan 14,379, dan @bangsamahasiswa dengan 14.092. Dengan demikian, konten yang berasal dari para top influencer menjadi ikon dari saluran aspirasi public, meskipun hal itu hanya dengan pemberian tanda suka (like) di setiap feed para top influencer Instagramdalam pembahasan RUU Cipta Kerja.

Sedangkan

untuk Instagramdiketahui ada beberapa narasi yang banyak mendapatkan atensi dari warganet. Narasi ini bermaterikan kritikan atas pembahasan RUU Cipta Kerja yang akan segera disahkan. Beberapa warganet yang menjadi top influencer ini membuat narasi yang cukup keras menolak RUU Cipta Kerja. Seperti yang diunggah oleh akun @47194929 yang menceritakan bahwa RUU Cipta Kerja akan disahkan, maka dari itu akun ini mengajak masyarakat untuk peduli dengan melakukan penolakan melalui media sosial masing-masing. "Kemarin malam pemerintah dan DPR RI sepakat melanjutkan pembahasan RUU Cipta Kerja atau Omnibus Law ke Rapat Paripurna DPR RI. Kemungkinan besar hari kamis nanti akan disahkan, tidak peduli seberapa banyak suara penolaka dari rakyat. Kami mengajak kamu yang peduli pada nasib masyarakat dan lingkungan untuk terus menunjukan perjuanganmu dengan menyuarakan penolakan melalui media sosial masing-masing selama tiga hari kedepan. Cek Instagramstory. “\#BatalkanOmnibusLaw

\#TolakOmnibusLaw \#JegalSampaiGagal \#MosiTidakPercaya. Akun selanjutnya yang memiliki narasi terbaik adalah akun @1428131216 yang merasa pesimis terhadap pemerintah selaku pembuat kebijakan RUU Cipta Kerja, karena tetap melanjutkan pembahasan meskipun mendapat banyak kritikan dari masyarakat luas. Seperti unggahanya berikut ini "Omnibus Law; Ancaman di Malam Minggu. Malam Minggu ini DPR dan Pemerintah lagi-lagi "pacarana” Kembali menghasilkan jahatnya; Pembehasan Omnibus Law dilanjutkan. Rupanya tidak ada istirahat untuk hal-hal jahat. Pembahasan Omnibus Law masih mau dilanjutkan, meski mendapat banyak kritik dari masyarakat. Lantas, hari ini pada siapa kita harus menaruh percaya? \#GagalkanOmnibusLaw,\#JegalSampaiGa gal, \#MosiTidakPercaya."

Lebih lanjut, akun @Kolektifa yang kecewa dengan wakil rakyat karena memanfaatkan masa pandemi Covid-19 untuk terus membahas RUU Cipta Kerja hingga akan segera disahkan. Bahkan, akun 
ini menilai wakil rakyat dan pemerintah telah menutup telingga dari suara rakyat yang menolak RUU Cipta Kerja. Seperti yang diutarakanya berikut ini; "Cilaka Di Depan Mata diteruskan dari @fraksirakyat_id Omnibus Law sudah di depan rumahmu. Malam ini, 3 Oktober 2020 pemerintah dan DPR sepakat untuk melanjutkan pembahasan Omnibus Law. Besar kemungkinan tidak lama lagi akan disahkan. Semakin kencang suara penolakan dari rakyat maka semakin kencang pemerintah dan DPR menutup telinganya. Terlebih mereka memanfaatkan pandemi Covid-19 untuk memuluskan rencananya.\#BatalkanOmnibusLaw,\#Jega lSampaiGagal,\#MosiTidakPercaya,\#Gaga lkanOmnibusLaw, \#RUUCiptaKerja”. Dengan demikian, berbagai narasi yang tercipta dalam akun-akun Instagrammenunjukan kekecewaan warganet akan rencana disahkanya RUU Cipta Kerja. Identifikasi dari berbagai narasi ini semakin menunjukan bahwa media sosial sangat efektif menjadi salah satu saluran aspirasi kewargaan.

Lebih lanjut dalam Instagramselain konten yang mempengaruhi para warganet untuk menyampaikan segala aspirasinya adalah melalui tagar (hashtags). Peran tagar dalam Instagramtentu tidak sama dengan Twitter, sebab untuk Instagramtagar (hashtags) berfungsi sebagai pengelompokan konten semata. Tagar dalam Instagram tidak mengenal waktu dan akan terus bertambah seiring penggunaan tagar tersebut oleh warganet. Berikut beberapa tagar yang paling banyak digunakan oleh warganet dalam pembahasan RUU Cipta Kerja.

\section{Gambar 7 Top Hashtags Instagram}

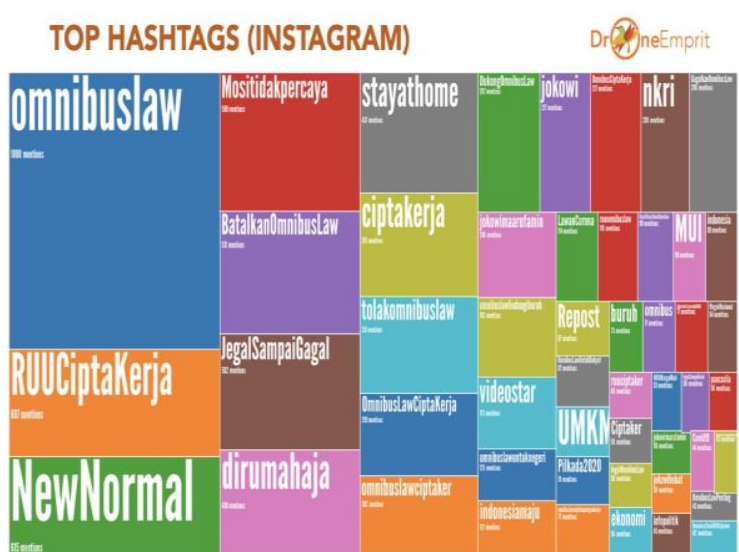

Sumber : pers.droneemprit.id

Dalam platform Instagramterdapat beberapa tagar yang cukup menarik perhatian warganet diantaranya; \#OmnibusLaw, \#RUUCiptaKerja dan \#NewNormal. Tagar (hashtags) ini sebagai simbol dari bentuk saluran aspirasi warganet. Untuk kluster yang menolak, tentulah tagar menjadi saluran dalam menyampaikan aspirasi penolakan yang selama digulirkan oleh warganet. Dari analisis Drone Emprit mengenai tagar ini dapat disimpulkan bahwa dalam media sosial terutama Instagramperan tagar (hashtags) sangat dominan dalam membangun opini publik.

Pada akhirnya, percakapan yang timbul terkait pembahasan RUU Cipta 
Kerja di media sosial telah mengonfirmasi bahwa warganet dapat menyalurkan semua aspirasinya melalui saluran media sosial. Terutama dalam memberikan berbagai masukan yang konstruktif dan argumentatif seputar pembahasan RUU Cipta Kerja. Dengan demikian penggunaan media sosial dalam konteks penelitian ini menjadi salah satu saluran untuk berpartisipasi aktif dalam isu politik dan pemerintahan. Meskipun partisipasi digital tersebut hanya diterjemahkan melalui konten, narasi dan frasa yang ditampilkan dalam setiap postingan di media sosial masing-masing.

\section{KESIMPULAN}

Media sosial memiliki peran strategis dalam mendorong pelembagaan karakter partisipatoris dalam langgam demokrasi di Indonesia. Hal itu dapat dilacak dari peran media sosial yang bisa membuat setiap warga negara untuk ikut berpartisipasi terhadap isu terkini tentang politik dan pemerintahan. Dikarenakan media sosial memiliki karakter partisipatif yang secara tidak langsung dapat mengajak warga negara untuk bisa berpartisipasi dalam segala hal, seperti memberikan sanggahan, kritikan hingga argumentasi yang konstuktif. Dalam konteks pembahasan RUU Cipta Kerja media sosial telah mendorong para warganet untuk dapat menyampaikan semua aspirasinya masingmasing. Hal itu dapat dilacak dari beberapa narasi yang diunggah di Twitter dan Instagrambermaterikan

kritikan, kekecewaan hingga ajakan untuk menolak RUU Cipta Kerja. Selain itu ada pula narasi yang mengajak warganet lainnya untuk berpartisipasi aktif secara massif dalam menolak RUU Cipta Kerja melalui media sosial masing-masing. Alhasil, kehadiran narasi yang konstruktif dan argumentatif semakin menegaskan bahwa warganet dapat dengan mudah menyampaikan semau aspirasinya terkait pembahasan RUU Cipta Kerja.

Partisipasi aktif lainnya tampak dari banyaknya kehadiran tagar (hashtags) yang memiliki kata kunci penolakan terhadap RUU Cipta Kerja. Tagar-tagar ini dibuat dan diperkuat oleh warganet yang merasa kecewa terhadap pembahasan RUU Cipta Kerja. Akibatnya terjadi peningkatan percakapan melalui tagar \#MosiTidakPercaya yang kemudian menjadi trending topik baik di Indonesia dan dunia. Dengan kata lain, para warganet telah memanfaatkan media sosial secara efektif untuk menyalurkan aspirasinya masing-masing. Dengan demikian artikel ini menyatakan bahwa media sosial telah berkontribusi positif menjadi saluran aspirasi kewargaan yang efektif dalam menyikapi berbagai isu terkini terutama perihal politik dan pemerintahan. 


\section{DAFTAR PUSTAKA}

Abubakar, A. A. (2012). Political participation and discourse in social media during the 2011 Presidential Electioneering. The Nigerian journal of communication, 10(1), 96-116.

Adji, W. S., Bashith, A., Nasith, A., \& Amin, S. (2019). Identification of Social Symptoms Using the Drone Emprit Academic as a Support for Statistical Literacy. Abjadia: International Journal of Education, 04(02), 97-106.

Arianto, B. (2019). Kontestasi Relawan Teman Ahok dalam Pemilihan Kepala Daerah DKI Jakarta 2017. Journal of Social Politics and Governance, 1(1), 40-55.

(2020a). Salah Kaprah Ihwal

Buzzer : Analisis Percakapan Warganet di Media Sosial. Jurnal Ilmiah Ilmu Pemerintahan (JIIP) Undip, 5 (1), 1-20. (2020b). Analisis Peran Buzzer

Media Sosial dalam Memperkuat Kampanye Petani Milenial. Jurnal Riset Komunikasi Universitas Sultan Ageng Tirtayasa, 01 (02), 168-187. (2020c). Pemanfaatan Aplikasi

Drone Emprit Academic dalam Menganalisis Opini Publik di Media Sosial. Journal of Social Politics and Governance, 2(2), 177-191.
Bennett, W. L. (2012). The personalization of politics: Political identity, social media, and changing patterns of participation. The annals of the American academy of political and social science, 644(1), 20-39.

Bentivegna, S. (2006). Rethinking politics in the world of ICTs. European journal of communication,21(3), 331-343.

Castells, M. (2001) The Internet Galaxy. Oxford: Oxford University Press.

Chandra, E. (2018). Youtube, Citra Media Informasi Interaktif Atau Media Penyampaian Aspirasi Pribadi. Jurnal Muara Ilmu Sosial, Humaniora, dan Seni, 1(2), 406-417.

Cnnindonesia.com. (2020). https://www.cnnindonesia.com/nasio nal/20200508201138-12501485/kronologi-prank-sembakoke-waria-youtuber-ferdian-paleka Coleman, S., Taylor, J. A., \& Van de Donk, W. (1999). Parliament in the Age of the Internet. Parliamentary Affairs, 52(3), 365-370.

Effing, R., Van Hillegersberg, J., \& Huibers, T. (2011, August). Social media and political participation: are Facebook, Twitter and YouTube democratizing our political systems?. In International conference on 
electronic participation (pp. 25-35).

Springer, Berlin, Heidelberg.

Enikolopov, R., Makarin, A., \& Petrova, M. (2019). Social media and protest participation: Evidence from Russia. Available at SSRN 2696236.

Fahmi. I. (2019). Drone Emprit : Software for Social Media Monitoring and Analytics. Available at http://pers.droneemprit.id

Gil de Zúñiga, H., Molyneux, L., \& Zheng, P. (2014). Social media, political expression, and political participation: Panel analysis of lagged and concurrent relationships. Journal of communication, 64(4), 612-634.

Howard, Philip N., and Malcolm R. Parks. "Social media and political change: Capacity, constraint, and consequence." (2012): 359-362.

Jati, W. R. (2016). Aktivisme kelas menengah berbasis media sosial: Munculnya relawan dalam pemilu 2014. Jurnal Sosial dan Ilmu Politik.

Kaplan, A \& Michael Haenlein (2010). Users of the world, unite! The challenges and opportunities of Social Media. Business Horizons, 53 (1), 59-68.

Lee, F. L., Chen, H. T., \& Chan, M. (2017). Social media use and university students' participation in a large-scale protest campaign: The case of Hong Kong's Umbrella
Movement. Telematics and Informatics, 34(2), 457-469.

Lewis, S., Pea, R., \& Rosen, J. (2010). Beyond participation to co-creation of meaning: mobile social media in generative learning communities. Social Science Information, 49(3), 351-369.

Literat, I., Kligler-Vilenchik, N., Brough, M., \& Blum-Ross, A. (2018). Analyzing youth digital participation: Aims, actors, contexts and intensities. The Information Society, 34(4), 261-273.

Luna-Reyes, L. F. (2017). Opportunities and challenges for digital governance in a world of digital participation. Information polity, 22(2-3), 197-205.

Loader, Brian D., and Dan Mercea. "Networking democracy? Social media innovations and participatory politics." Information,

Communication \& Society 14 , no. 6 (2011): 757-769.

McQuail, D. (2005) McQuail's Mass Communication Theory. Fifth Edition London. SAGE Publications Ltd.

Perangin-angin, L. L., \& Zainal, M. (2018). Partisipasi Politik Pemilih Pemula Dalam Bingkai Jejaring Sosial Di Media Sosial. Jurnal Aspikom, 3(4), 737-754. 
Rcfra.org.

(2021).

https://rcfra.org/2021/03/19/5-besar-

platform-media-sosial-terfavorit-di-

indonesia/

Rishika, R., Kumar, A., Janakiraman, R., \& Bezawada, R. (2013). The effect of customers' social media participation on customer visit frequency and profitability: an empirical investigation. Information systems research, 24(1), 108-127.

Suharso, P. (2019). Pemanfaatan Drone Emprit dalam Melihat Trend Perkembangan Bacaan Digital melalui Akun Twitter. Anuva, 3(4), 333-346. 